\title{
PELATIHAN PENGOLAHAN DAN PENGEMASAN JAMUR TIRAM MENJADI BAKSO DI DESA PENINJOAN, KECAMATAN TEMBUKU, KABUPATEN BANGLI
}

\author{
A. A. Istri Sri Wiadnyani ${ }^{1}$, I. M. Sugitha ${ }^{2}$, I W. R. Widarta ${ }^{3}$, I.D.P. Kartika, P. ${ }^{4}$
}

\begin{abstract}
ABSTRAK
Desa Peninjoan terletak di Kecamatan Tembuku, Kabupaten Bangli. Jamur tiram merupakan salah satu komoditas pertanian di desa ini. Masyarakat pedesaan di desa Peninjoan belum berpengalaman bagaimana membuat bakso jamur tiram. Tujuan kegiatan ini untuk mengenalkan bakso dari jamur tiram dan untuk meningkatkan nilai tambahnya. Pengabdian dilakukan dengan 2 metode, yaitu: pertama, informasi dan diskusi dengan masyarakat pedesaan tentang produk sampingan jamur tiram. Kedua, produksi dan pelatihan olahan jamur tiram, kemasan dan pelabelan. Ada 25 peserta dalam pengabdian ini, termasuk anggota kelompok tani Lancar Abadi. Mereka memberi respon positif atas pengabdian ini.
\end{abstract}

Kata kunci : Desa peninjoan, jamur tiram, bakso, Kelompok Tani Lancar Abadi.

\begin{abstract}
Peninjoan's village located on Tembuku sub-district in Bangli regency. Oyster mushroom is one of agriculture commodities in this village. Rural community in Peninjoan village inexperienced how to make meatballs by oyster mushroomo-by product. The aim of these activities to introduce meatballs production by oyster mushroom-by product to increase value added it. Devotion was carried out by 2 method, namely: first, information and discussion with rural community about oyster mushroom by-product. Second, oyster mushroom production training, packaging and labeling training. There are 25 partisipant in these devotion, included delegation of farmer groups lancer Abadi. They given positif response for these devotion.
\end{abstract}

Key words : Peninjoan`s Village, oyster mushroom, meatballs, Lancar Abadi farmer groups

\section{PENDAHULUAN}

Desa Peninjoan termasuk salah satu desa yang terletak di Kecamatan Tembuku, Kabupaten Bangli. Jarak desa tersebut dari kota Denpasar adalah $\pm 75 \mathrm{~km}$ dengan waktu tempuh \pm 2 jam. Kecamatan Tembuku terdiri dari 6 desa yaitu Undisan, Peninjoan, Yangapi, Jehem, Tembuku dan Bambang. Batas wilayah desa Peninjoan adalah sebelah utara desa yang api, sebelah selatan Desa Undisan, timur Desa Rendang kabupaten Karangasem dan Barat Desa Undisan (Anon, 2016 b). Desa Peninjoan dianggap sebagai salah satu desa terpencil dan dianggap daerah miskin sehingga banyak sekali bantuan pemerintah dalam hal pemenuhan kebutuhan pangan, sandang dan papan kepada warga miskin.

Mata pencaharian sebagian besar penduduk Desa Peninjoan adalah petani. Salah satu hasil pertanian yang sedang berkembang di Desa Peninjoan adalah pertanian jamur tiram dan sudah

1,2,3,4 Jurusan Ilmu dan Teknologi Pangan, Fakultas Teknologi Pertanian Universitas Udayana. Email : asriwiadnyani@yahoo.com 
terdapat kelompok Tani ( KT) Lancar Abadi yang bergerak pada pertanian jamur tiram. Letak geografis dan suhu serta lingkungan yang sesuai untuk pertumbuhan jamur di Desa Peninjoan (Anon, 2016 a).

Jamur Tiram di Desa Peninjoan, Kecamatan Tembuku, Bangli mempunyai potensi yang menjanjikan namun belum termanfaatkan secara optimal karena hanya dijual dalam bentuk segar dan dimanfaatkan untuk diolah menjadi cah jamur, oseng-oseng dan sup jamur, padahal jamur tiram dapat juga digunakan sebagai suatu usaha produksi di bidang pangan oleh warga untuk menambah penghasilan keluarga miskin di Desa Peninjoan. Jamur tiram sangat mudah dibudidayakan dengan produksi yang sangat tinggi. Terdapat Kelompok Tani jamur tiram di Desa Peninjoan mampu memproduksi 100 sampai $150 \mathrm{~kg} / \mathrm{hari}$ tapi hanya menjual jamur tiram dalam bentuk segar tanpa dilakukan pengolahan lebih lanjut. Di Desa Peninjoan terdapat kelompok wanita tani yang melakukan kegiatan menjahit ataupun membuat jajanan tradisional pada saat upacara keagamaan yang tentu saja penganan tradisional yang bersifat basah/semi basah sehingga memeliki umur simpan yang relatif pendek, padahal ada kelompok petani jamur yang mampu memproduksi jamur yang berlimpah yang nantinya dapat diharapkan KT dan KWT dapat bersinergi dalam mensuplai dan mengolah jamur tiram menjadi produk olahan yang bermanfaat dan bernilai gizi tinggi.

Untuk meningkatkan pengetahuan masyarakat Desa Peninjoan terutama tentang diversifikasi pengolahan rumput laut agar dapat dijadikan sebagai alternatif dalam mengembangkan potensi swadaya masyarakat dalam berwirausaha maka dipandang perlu untuk memberikan pengetahuan tambahan tentang pengolahan dan teknik pengemasan Jmur tiram menjadi bakso. Oleh karena itu, penyuluhan, pelatihan, dan pengenalan proses pengolahan lanjutan dari jamur tiram menjadi produk-produk olahan yang mempunyai nilai ekonomis yang lebih tinggi merupakan langkah yang tepat.

\subsection{Tujuan dan Manfaat Kegiatan}

Memperkenalkan teknologi pengolahan jamur tiram menjadi bakso dikuti dengan teknik pengemasan (packing) dan teknik pelabelan (labeling) sehingga menjadi produk-produk yang memiliki nilai ekonomis lebih tinggi sekaligus merupakan makanan pendamping yang bergizi karena kandungan protein, serat, vitamin dan mineralnya. Manfaat kegiatan ini adalah Peningkatan pengetahuan dan ketrampilan berupa teknologi tepat guna khususnya dalam pengolahan jamur tiram menjadi bakso yang kaya asam amino, serat, vitamin dan mineral yang berguna bagi kesehatan petani dan masyarakat desa Peninjoan, Tembuku-Bangli. Manfaat bagi pemerintah daerah adalah perolehan masukan dalam bentuk teknologi pengolahan jamur tiram menjadi bakso serta upaya ikut serta memberdayakan potensi masyarakat bagi pembangunan desa Peninjoan-Bangli

\subsection{Khalayak Sasaran Strategis}

Khalayak sasaran dalam kegiatan ini adalah petani, ibu PKK, ibu rumah tangga, kelompok tani mitra (KT )"Lancar Abadi dan KWT yang ada di Desa Peninjoan, Tembuku-Bangli.

\section{METODE PELAKSANAAN}

Pelaksanaan kegiatan dilakukan dengan:

1. Memberikan pelatihan dan penyuluhan tentang cara pengolahan Jamur tiram menjadi. bakso Pelaksanaan pelatihan ini di samping diberikan secara lisan dengan pemaparan cara pembuatan 
bakso jamur dilengkapi diagram alir proses pengolahan, juga diberikan brosur/makalah mengenai teknologi pengolahan jamur tiram menjadi bakso yang memiliki kandungan protein dan serat yang tinggi.

2. Memberikan praktek kegiatan pengolahan jamur tiram menjadi bakso yang siap dikonsumsi dan dipasarkan.

3. Memberikan teknik pengemasan dan teknik pelabelan pada produk bakso jamur sehingga dapat meningkatkan umur simpan produk dan juga meningkatkan nilai ekonomisnya

\section{HASIL YANG DICAPAI}

Kegiatan pengabdian kepada masyarakat dilakukan dalam bentuk pelatihan dan praktek langsung pengolahan rumput laut menjadi selai disertai dengan teknik pengemasan dan pelabelan kepada KT Lancar Abadi dan ibu-ibu rumah tangga yang bertempat di Rumah produksi KT lancer Abadi. Kegiatan ini dapat dikatakan berhasil dilaksanakan dengan baik sesuai dengan harapan baik dari segi rencana, jadwal kegiatan, respon masyarakat dan pencapaian tujuan, sasaran, target serta manfaat kegiatan.

\subsection{Penyuluhan Produk Olahan Jamur Tiram}

Pelaksanaan pengabdian melalui ceramah dan pelatihan pembuatan produk olahan rumput laut dapat memperkenalkan dan memberikan pengetahuan tambahan kepada ibu-iburumah tangga maupun kepada KT Lancar Abadi tentang teknologi tepat guna yag sederhana dalam pengolahan rumput laut menjadi selai sehingga ibu-ibu maupun anggota KT dapat menerapkannya di rumah tangga ataupun kelompoknya sekaligus mempertahankan nilai ekonomis jamur tiram disaat panen raya. Program ini mendapat sambutan yang baik. Hal ini terlihat dari tingginya antusias peserta yang hadir..

\section{Ceramah}

Pemberian ceramah kepada Kelompok Tani Lancar Abadi tentang cara pembuatan bakso pada tanggal 15 Agustus 2017. Ceramah dilakukan terhadap 25 orang. Peserta Pelatihan terlihat sangat antusias dan aktif mengajukan pertanyaan.

\section{Pelatihan}

Pemberian pelatihan KT Lancar Abadi tentang pengolahan jamur tiram menjadi bakso, dilakukan pada tanggal 15 Agustus 2017. Pelatihan dilakukan dalam bentuk demonstrasi dan praktek langsung. Peserta pelatihan terlihat sangat antusias dan interaktif. Terbukti dengan banyaknya pertanyaan sehinnga diskusi 2 arah sangat kondusif. 
Pelatihan Pengolahan Dan Pengemasan Jamur Tiram Menjadi Bakso Di Desa Peninjoan, Kecamatan Tembuku, Kabupaten Bangli

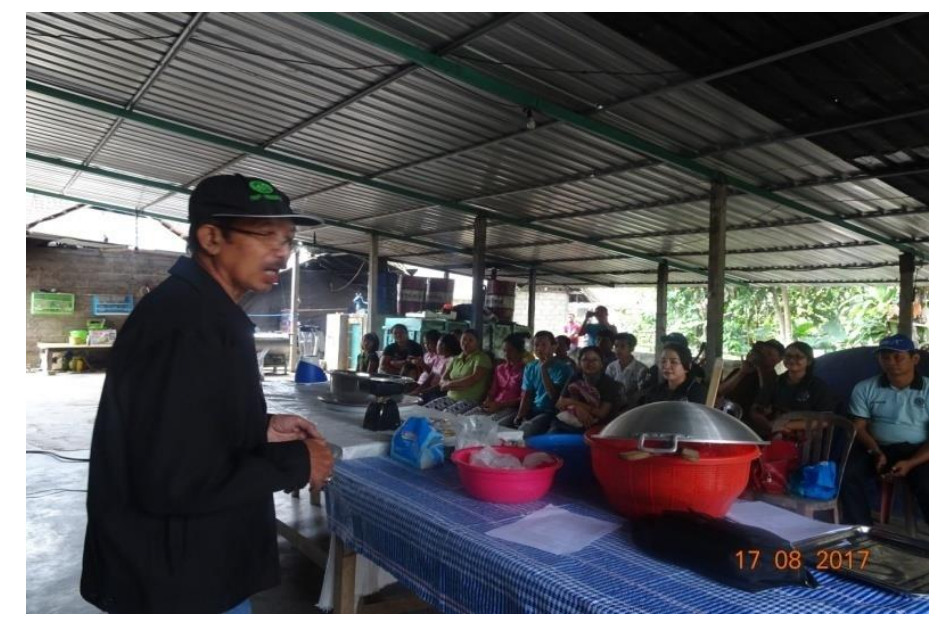

Gambar 1. Foto Ceramah Pembuatan Bakso jamur
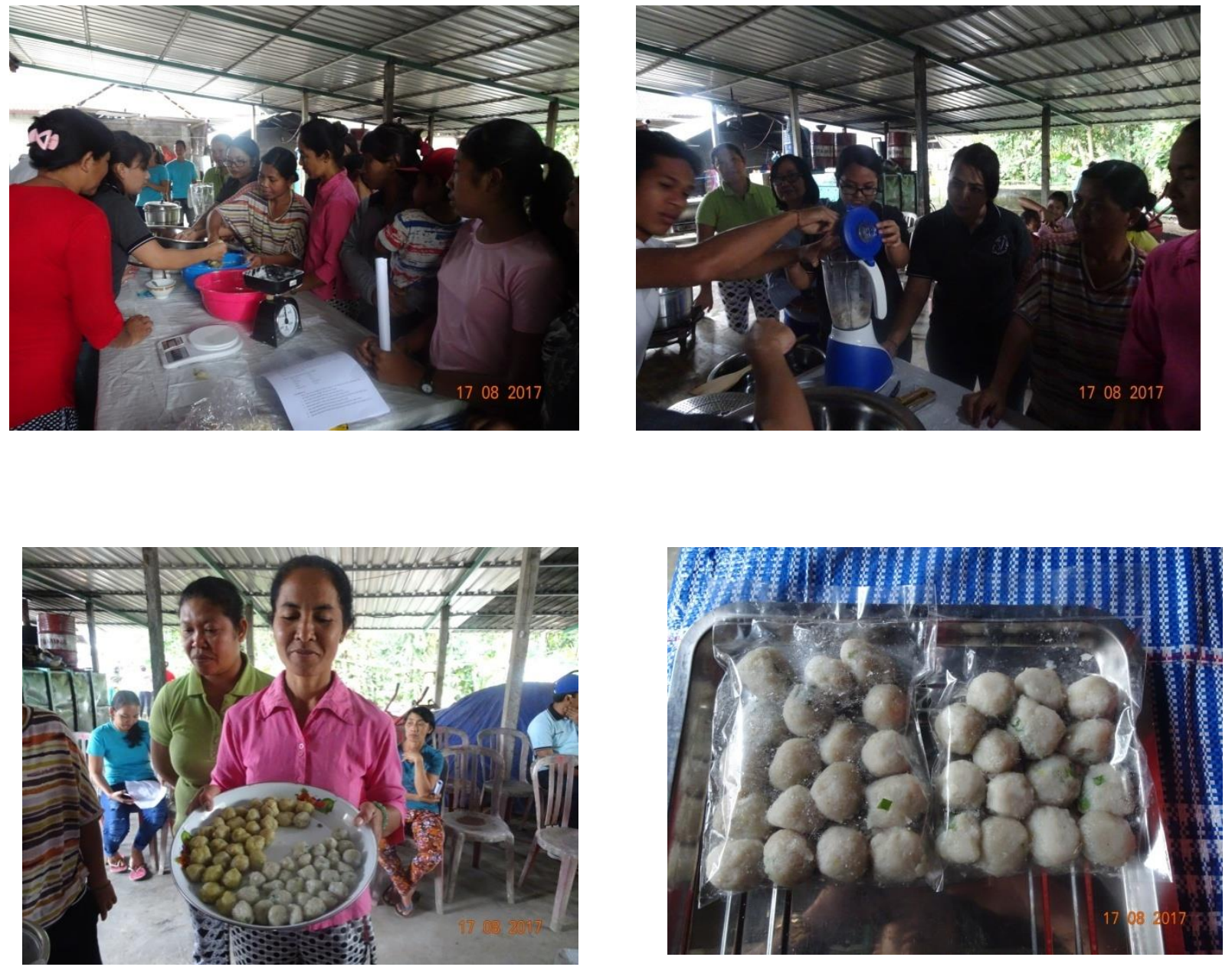

Gambar 2. Foto Praktek Pembuatan Bakso Jamur 


\subsection{PENGEMASAN DAN PELABELAN}

Mengingat akan pentingnya fungsi dari pengemasan dan pelabelan, maka kami memberikan penyuluhan dan praktek langsung cara mengemas produk yang mereka telah hasilkan pada tanggal 12 September 2017. Pemberian merek dagang tak kalah pentingnya yang memiliki 2 fungsi utama yaitu sebagai identitas bagi produk dan sebagai pembeda produk dalam bisnis yang dimiliki dengan para pesaing. Manfaat merek dalam suatu bisnis selain sebagai identitas dan membedakan dengan pesaing dapat juga untuk meningkatkan penjualan.

Untuk desain label kemasan pada produk kami membantu mendesainkannya sebelumnya dan disesuaikan dengan cirri khas desa Peninjoan, dalam hal ini tetap kami komunikasikan pada saat penyuluhan untuk menerima masukan dari anggota Kelompok Tani. Penyuluhan dan praktek langsung pengemasan serta pelabelan produk biskuit dan dodol dilaksanakan tanggal 12 September 2017 dengan merek dagang pada selai adalah BAKSO SEHAT. Pengemas primer pada bakso berupa plastic Polietilen ( PE ) dengan label yang sesuai dengan persyaratan yang telah ditentukan.
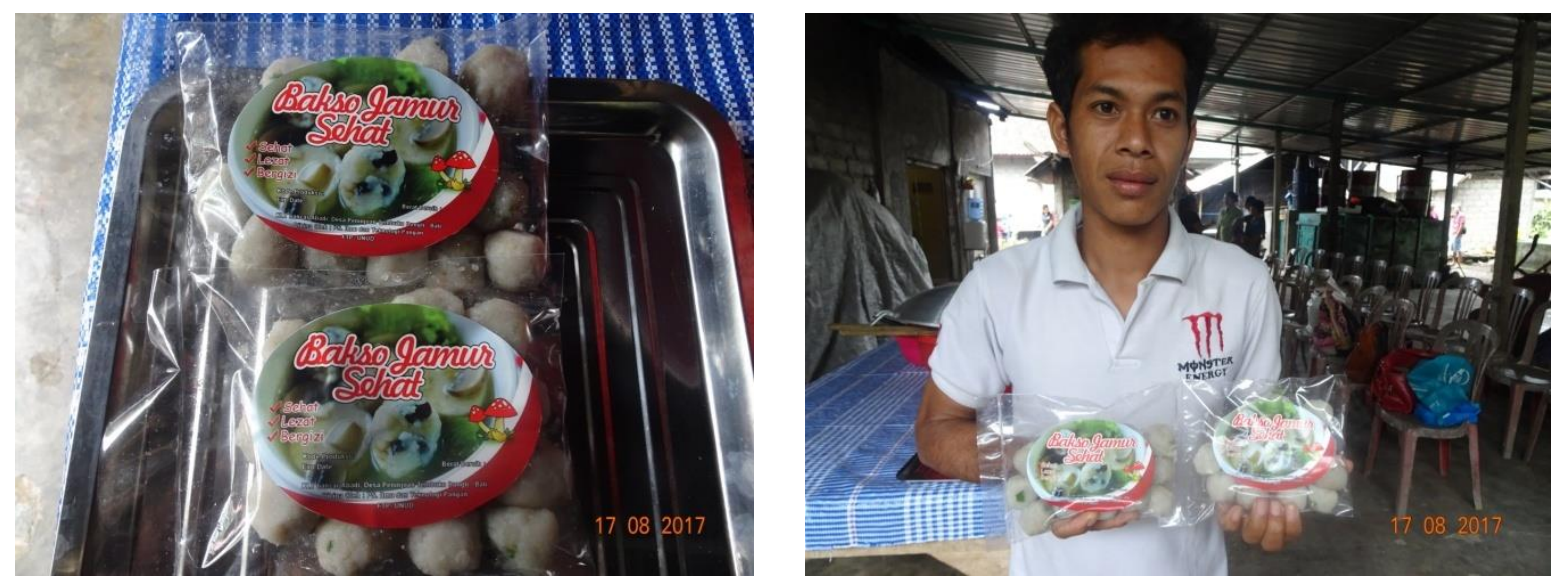

Gambar 3. Foto bakso jamur dengan pengemas plastik PE dan label

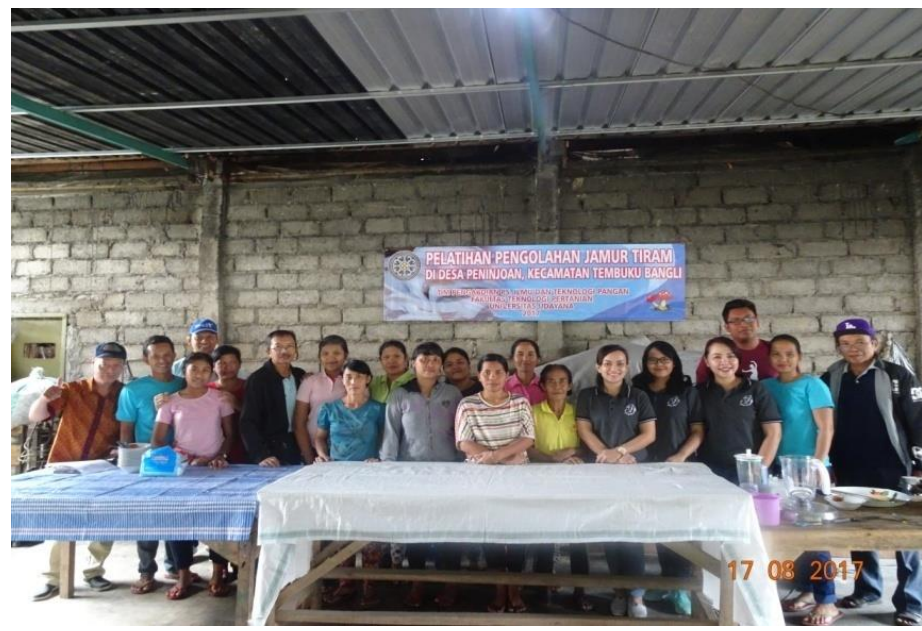

Gambar 4. Foto Bersama Usai pelatihan 


\section{KESIMPULAN DAN SARAN}

Adapun kesimpulan yang dapat diperoleh adalah:

1. Kegiatan pengabdian ini dilaksanakan dalam bentuk penyuluhan dan pelatihan pengolahan jamur tiram menjadi bakso jamur pada KT Lancar Abadi di Br Tampuagan, Desa Peninjoan, Kecamatan Tembuku, Kabupaten Bangli

2. Pelatihan teknik pengemasan dan pelabelan juga diberikan pada KT Lancar Abadi

3. Kegiatan pelatihan dapat dikatakan berhasil, karena dapat terlaksana dengan baik dan respon masyarakat yang sangat positif yang terlihat dari keaktifan peserta selama diskusi dan pelatihan berlangsung.

4. Kegiatan ini sudah terlaksana $100 \%$ dan para KT mampu memproduksi bakso jamur dengan Merk dagang BAKSO SEHAT guna mencapaian tujuan untuk menaikan status Kelompok tani menjadi UKM

\section{Saran}

Melihat respon masyarakatdan Kelompok Tani Lancar Abadi yang tinggi terhadap pelatihan Pengolahan jamur tiram menjadi bakso di Desa Peninjoan, Kecamatan Tembuku, Kabupaten Bangli, maka diperlukan kegiatan serupa di daerah-daerah lain. Kegiatan ini akan lebih bermanfaat apabila di tahun berikutnya KT Lancar Abadi :

1. Diberikan pelatihan manajemen pemasaran yang lebih baik sehingga mampu memasarkan tidak secara konvensional tetapi juga melalui internet dengan pembuatan website.

2. Pelatihan dan penyuluhan sanitasi (produksi, peralatan ruang kerja) dan Higeinis pekerja pengolahan

\section{UCAPAN TERIMAKASIH}

Kepada DIPA PNBP Universitas Udayana Sesuai dengan Surat Penugasan Pelaksanaan Pengabdian Kepada Masyarakat Nomor 674-90/UN 14.4A/PM/2017, tanggal 12 Juli 2017

\section{DAFTAR PUSTAKA}

Anonimus. 2001. Teknologi Tepat Guna Agroindustri Kecil Sumatera Barat, Hasbullah, Dewan Ilmu Pengetahuan, Teknologi dan Industri Sumatera Barat.

Anonimus. 2010. Olahan Jamur Tiram. Liputan6.com, Badung.

Anonimus . 2016 a. http://www.gerbangsadumandara.provbali.info/kecamatan-tembuku-2/desapeninjoan.html. Diakses 20 Mei 2016

Anonimus.2016b.http://www.kemendagri.go.id/pages/profildaerah/kabupaten/id/51/name/bali/detail/5106/bangli. Diakses 20 Mei 2016

Anonimus. 2016c. https://id.wikipedia.org/wiki/Peninjoan, Tembuku, Bangli. Diakses 20 Mei 2016

Desrosier, N.W., 1988. Teknologi Pengawetan Pangan. UI-Press, Jakarta.

Julianti, E., Mimi, N. 2006. Teknologi Pengemasan. Bahan Ajar Fakultas Pertanian Universits Sumatera Utara

Johan, M. 2014. kandungan nutrisi baglog jamur tiram putih (pleurotus ostreatus) sebagai bahan pakan ternak pada masa inkubasi yang berbeda. Universitas hasanuddin , makassar 